ISSN 0103-5150

Fisioter. Mov., Curitiba, v. 27, n. 4, p. 591-599, out./dez. 2014

Licenciado sob uma Licença Creative Commons

DOI: http://dx.doi.org.10.1590/0103-5150.027.004.A011

\title{
Influence of body weight unloading and support surface during walking of children with cerebral palsy
}

\author{
Influência do alívio de peso corporal e da superfície de suporte \\ durante o andar de crianças com paralisia cerebral espástica
}

\author{
Melissa Leandro Celestino $^{[\mathrm{a}]}$, Gabriela Lopes Gama ${ }^{[\mathrm{b}]}$, Gabryella Santos Cordeiro Longuinho ${ }^{[\mathrm{c}]}$, \\ Meico Fugita $^{[\mathrm{d}]}$, Ana Maria Forti Barela ${ }^{[\mathrm{e}]}$ \\ [a] PhD student, Programa de Pós-Graduação em Ciências do Desenvolvimento Humano, Instituto de Ciências da Atividade \\ Física e Esporte, Universidade Cruzeiro do Sul, São Paulo, SP - Brazil, e-mail: melissalcelestino@gmail.com \\ [b] PhD student, Programa de Pós-Graduação em Ciências do Desenvolvimento Humano, Instituto de Ciências da Atividade \\ Física e Esporte, Universidade Cruzeiro do Sul, São Paulo, SP - Brazil, e-mail: gabilopes_@hotmail.com \\ [c] Graduated in Physical Education, Universidade Cruzeiro do Sul, São Paulo, SP - Brazil, e-mail: \\ gaby.longuinho@hotmail.com \\ [d] PhD in Physical Education, Instituto de Ciências da Atividade Física e Esporte, Universidade Cruzeiro do Sul, São Paulo, \\ SP - Brazil, e-mail: meico.fugita@gmail.com \\ [e] $\mathrm{PhD}$ in Physical Education, associate professor, Physical Education undergraduate and Graduate Program in Human \\ Movement Sciences, Universidade Cruzeiro do Sul, São Paulo, SP - Brazil, e-mail: ana.barela@cruzeirodosul.edu.br
}

\section{Abstract}

Introduction: Partial body weight support (BWS) systems have been employed for gait training of children with cerebral palsy (CP). Therefore, it would be important to analyze if the type of walking surface and the amount of body weight unloading over lower limbs change the way these children walk. Objectives: Investigate the influence of walking surface and amount of body weight unloading on the spatial temporal characteristics during walking of children with CP. Materials and methods: Seven children with spastic CP between four and eight years old and GMFCS (Gross Motor Function Classification System) between I and IV, were videotaped walking with $0 \%, 15 \%$ and $30 \%$ of BWS on both dynamic (treadmill) and static (ground level) surfaces. Walking spatial temporal variables were calculated. Results: Children walked with similar velocity in all experimental conditions. While stance duration decreased as the percentage of BWS 
increased, no differences were found for stance and swing periods and cadence. Children walked with longer steps and strides and with faster strides on static surface compared to dynamic surface. Conclusion: Children with $\mathrm{CP}$ presenting different levels of motor impairment presented some alterations in the spatial temporal walking parameters as they walked with body unloading. However, such alterations might be due mainly to the type of walking surface than the percentage of body weight unloading on lower limbs.

Keywords: Gait. Partial body weight support system. Spatial-temporal parameters.

\section{Resumo}

Introdução: Sistemas de suporte parcial de peso corporal (SPPC) têm sido utilizados para treinamento do andar de crianças com paralisia cerebral (PC). Sendo assim, seria importante analisar se o tipo de superfície e a quantidade de alívio de peso corporal sobre os membros inferiores interferem na forma como essas crianças andam. Objetivo: Investigar a influência do tipo de superfície e da porcentagem de alívio de peso corporal sobre as características espaço-temporais durante o andar de crianças com PC. Materiais e métodos: Sete crianças com PC espástica, entre quatro e oito anos de idade, e GMFCS (Gross Motor Function Classification System) entre I e IV, foram filmadas andando com 0\%, 15\% e 30\% de SPPC em superfícies móvel (esteira motorizada) e fixa (chão). Variáveis espaço-temporais do andar foram calculadas. Resultados: As crianças andaram com velocidade semelhante em todas as condições experimentais. Enquanto que a duração do período de apoio diminuiu conforme a porcentagem de SPPC aumentou, nenhuma diferença para as fases de apoio e balanço e cadência foi encontrada. As crianças andaram com passos e passadas mais longos e passadas mais rápidas na superfície fixa do que na superfície móvel. Conclusão: Crianças com PC com diferentes níveis de acometimento motor apresentaram algumas alterações nos parâmetros espaço-temporais durante o andar com alívio de peso corporal em superfícies móvel e fixa. Entretanto, tais alterações podem ser atribuídas principalmente ao tipo de superfície em que as crianças andam do que às porcentagens de alívio de peso corporal proporcionadas aos membros inferiores.

Palavras-chave: Marcha. Sistema de suporte parcial de peso corporal. Parâmetros espaço-temporais.

\section{Introduction}

Cerebral palsy (CP) has been described as a group of disorders in movement and posture development that are permanent and cause daily life activity limitation. Such disorders are attributed to non-progressive disturbances that occurred in the developing fetal or infant brain $(1,2)$. Consequently, children with $\mathrm{CP}$ might present different functional abilities according to the location and extension of brain lesion (3), and difficulty to perform voluntary movements.

Walking is among different types of voluntary movements, which is one of the main locomotion human beings use to change from place to place and explore the environment. Specifically in children, walking acquisition is a fundamental landmark that might facilitate their motor, social and cognitive development and, consequently, promotes more autonomy. Biped walking is an acquired motor action $(4,5)$ and, although it seems a simple motor action, it requires the control of many elements, that transform it on a complex motor action.

Walking acquisition is one of the main goal of intervention programs for children with CP. Gait impairment in children with $\mathrm{CP}$ are due, mainly, to spasticity or abnormal muscular tonus, motor control diminished and poor balance (6), and in many cases, those children are not able to generate sufficient muscular force to maintain upright posture and ambulate around. In this way, a strategy that could promote upright posture maintenance and help in the balance of those children would be body weight unloading on the lower limb during the locomotion. This strategy is named body weight support or partial body weight support (BWS), and it 
has been employed as an alternative in the walking training (7-15).

The rationale for using BWS is that body weight unloading on lower limb would reduce the load that should be overcome by the individual, facilitating the steps execution and providing safety and stability (16). BWS systems that are used more often for gait training consist of a harness attached to the BWS. In this type of training, individual practices walking on a treadmill, considered as a moveable surface, as s/he body weight is partially unloaded by the BWS by the suspended harness.

Walking training with BWS presents many advantages for individuals enrolled in intervention programs. For example, BWS diminishes the body weight against gravity and the postural control request (17), low risk for falls and many possibilities to adjust the percentage of BWS (18), and symmetrically weight unloading on lower (15). On the other hand, the treadmill stimulates rhythmic and repetitive steps (15), promotes interlimb symmetry, improving walking temporal characteristics (19), and decrease the need for generating propulsive force during walking stance period, which many times constraints the locomotion of individuals with gait impairment (17).

To the best of our knowledge, there is no available information concerning if the BWS system is effective per se or if it is the combination of these systems and the walking surface that promotes the desired effect for the training. In this way, it is necessary to compare directly the possible effects of gait training in individuals with gait impairment employing the BWS system on both surfaces: over ground (20) and on a treadmill. The main reason for such investigation is that walking on a treadmill differs from walking over ground in many aspects (21-24), mainly for individuals who must acquire or reestablish locomotion. For example, context demands to walk on a treadmill and over ground are different, mainly in terms of propulsion and balance control. These aspects all together might constraint skill transfer from treadmill to over ground walking (17), which is the surface everyone walk on daily life. However, before having children with CP underwent to gait training with BWS, it is important to evaluate how they walk with different amount of body weight unloading on a treadmill and over ground.

Matsuno et al. (25) investigated children with CP walking with BWS on treadmill and over ground. Overall, these authors found that children with CP walked faster and presented longer and faster strides when they walked over ground compared to a treadmill. They presented higher cadence as they walked with no harness and with $0 \%$ BWS over ground compared to the treadmill with $0 \%$ and $30 \%$ BWS. The duration of single stance was longer and of double stance was shorter over ground compared to the treadmill. Although these results indicate that context demand might influence walking performance, mainly in terms of walking surface, it is important to note that the evaluated children were independent walkers. Based upon this first investigation (25), it was possible to note that children with hemiplegic $\mathrm{CP}$ are able to walk with BWS over ground and on treadmill. Next step would be to investigate if children with greater locomotion impairment could be able of walking with a BWS system on both walking surfaces and how they would react to each body weight unloading. Yet, considering that mean walking speed influences spatial temporal gait parameters, it is important to control the speed these children walk. As such, the goal of this study was to evaluate the effect of a BWS system controlled by a customized computer program, as children with $\mathrm{CP}$ walk over ground and on a treadmill. More specifically, the influence of three percentages of body weight unloading $(0 \%, 15 \%$ and $30 \%)$ and the walking surface (over ground and treadmill) on the spatial-temporal gait parameters were analyzed.

\section{Methods}

This study was approved by the Institutional Review Board at the Cruzeiro do Sul University, and all children's parents or legal guardians provided informed consent after explanation and agreement for participating in the study, according to the resolution 196/96 from CNS.

\section{Participants}

To take part of the study, the child should be diagnosed with hemiplegic or diplegic spastic CP; GMFCS (26) classification up to level IV; able to understand simple verbal commands; and not been undertaken any surgery at least six months before taking part in the study. Based upon these criteria, the study was released among professionals and places that 
assist these children. From a waiting list provided by some physical therapists, we made a phone call to the children's legal guardians and inform them about the goals of the study and invite them to visit the Movement Analysis Laboratory, Institute of Physical Activity and Sport Sciences, Cruzeiro do Sul University with their child.

Seven children with hemiplegia $(n=1)$ and diplegic $(n=6)$ spastic cerebral palsy, between four and eight years old took part in this study. Table 1 depicts the general characteristic about these children.

\section{Procedures}

The BWS system (FINIX Tecnologia, Ltda.) adopted in this study consists of two servo motors and one of them has a movement sensor that moves on a rail with speed controlled by a customized computational program (LabView, Inc.), and it can be used over ground and on a treadmill. In this system, a harness that allows adjustments around the trunk and thighs sustains the participant mechanically, and it is attached to a structure of the BWS system. This structure can be lowered or suspended by a cable connected to the servo motors. A load cell positioned between the structure and the cable, and connected to a digital display to monitor the desired amount of body weight. To unload the body weight, the participant stays still as one of the experimenters activate one of the servo motors increasing or decreasing the cable length. The rail that the system moves is approximately $7 \mathrm{~m}$ long and is sustained by steel beams at approximately $3 \mathrm{~m}$ from the floor. Five digital cameras (SONY DCR-HC28), displaced around the BWS system were used to acquire the data considered in this study.

After a familiarization period with the environment and experimenters, measurements of body mass and height were acquired. Following, reflective markers were placed on specific anatomical location of right and left body sides (although in this study only the markers placed on calcaneus were considered in the analysis). Each child wore a harness and walked with $0 \%, 15 \%$ and $30 \%$ BWS along a pathway covered with a rubber mat (over ground), and on a treadmill. The experimental conditions were randomized within and across children, and at least three trials (maximum of five trials) for each experimental condition. Before videotape each experimental condition, a period of adaptation was allowed and the speed that the child were able to walk was maintained for the three percentages of BWS. During the experimental session, all children were provided with rest periods as necessary.

Table 1 - General characteristics about the children with spastic cerebral palsy that participated in the study in terms of age (years), sex (male/female), body mass (kg), height (m) and gross motor functional level (GMFSC)

\begin{tabular}{cccccc}
\hline Child & Age & Sex & Mass & Height & GMFCS \\
\hline 1 & 8.3 & $\mathrm{~F}$ & 18.65 & 1.12 & II \\
2 & 4.6 & $\mathrm{~F}$ & 18.4 & 1.05 & IV \\
3 & 8 & $\mathrm{M}$ & 23.3 & 1.25 & II \\
4 & 7.6 & $\mathrm{M}$ & 22.7 & 1.19 & III \\
5 & 8 & $\mathrm{~F}$ & 15.3 & 1.02 & III \\
6 & 8.1 & $\mathrm{~F}$ & 21.8 & 1.28 & III \\
7 & 5 & $\mathrm{~F}$ & 17 & 1.08 & I \\
\hline Mean & $\mathbf{7 . 1 7}$ & & $\mathbf{1 9 . 7 9}$ & $\mathbf{1 . 1 4}$ & \\
MSE & $\mathbf{0 . 6 2}$ & & $\mathbf{1 . 2 4}$ & $\mathbf{0 . 0 4}$ & \\
\hline
\end{tabular}

Note: $\mathrm{M}=$ male; $\mathrm{F}=$ female; $\mathrm{MSE}=$ mean standard error 
Data analysis

Videotaped data were transferred to a computer and processed later with the computational program Ariel Performance Analysis System - APAS (Ariel Dynamics, Inc.). One intermediate stride per trial was selected, and the reflective markers were digitalized to obtain the coordinates $\mathrm{x}, \mathrm{y}, \mathrm{z}$, which were stored in text files. Events related to initial and final contacts of each foot on each surface were defined throughout visual inspection and registered. Based upon these events and on the coordinates from the markers placed on right and left calcaneus, the following variables were calculated using Matlab software (MathWorks, Inc.): stance duration, single stance and total double stance durations, and swing duration, step length, cadence, stride length and speed.

Data from both legs were averaged together for each trial and data from three trials under each experimental condition were averaged for each child. These data were used for the statistical analysis.

\section{Results}

Table 2 depicts means (mean standard error) values of mean walking speed on both surfaces and of the selected variables in the present study. The children walked with similar speed over ground and on treadmill $\left(\mathrm{F}_{1,6}=1.42, \mathrm{p}=0.278\right)$, and presented shorter stance period as the BWS unloading increased $\left(F_{2,12}\right.$ $=16.64, \mathrm{p}=0.000)$, regardless the walking surface $\left(F_{1,6}=3.95, p=0.094\right)$. Temporal organization was not affected either by the manipulation of walking surface (Wilks' Lambda $=0.35, \mathrm{~F}_{3,4}=2.53, \mathrm{p}=0.196$ ) or BWS unloading (Wilks' Lambda $=0.51, \mathrm{~F}_{6,20}=1.34$, $\mathrm{p}=0.287$ ), as single stance, total double stance and swing durations were similar among experimental conditions (Table 2).

The children walked with longer steps over ground compared to on the treadmill $\left(\mathrm{F}_{1,6}=16.84\right.$, $\mathrm{p}=0.006)$, independently of BWS unloading $\left(\mathrm{F}_{2,12}=\right.$ $3.38, p=0.068$ ), and presented similar cadence on both surfaces $\left(\mathrm{F}_{1,6}=1.66, \mathrm{p}=0.245\right)$. Finally, the children presented longer $\left(F_{1,6}=15.66, p=0.007\right)$ and faster $\left(F_{1,6}=18.44, p=0.005\right)$ strides over ground compared to on the treadmill (Table 2).

\section{Discussion}

This study investigated children with spastic CP walking with different body weight unloading over ground and on a treadmill. The results from this study revealed differences for some spatial-temporal gait parameters of these children in the investigated experimental conditions. It is important to note that these differences are not due to mean walking speed, which was similar among experimental conditions, but rather to manipulation of walking surface and body weight unloading on lower limbs. Previous studies investigated the use of BWS system in different surfaces $(9,25,27,28)$, however, the system used in the present study was different from the previous one concerning children with CP (25), and allowed to control the children's walking speed.

Table 2 - Mean (means standard error) of mean walking speed, duration of stance period, single stance, total double stance and swing, step length, cadence, stride length and speed in the different experimental conditions $0 \%$, $15 \%$ and $30 \%$ body weight support (BWS), over the ground (OG) and on the treadmill (TM)

(To be continued)

\begin{tabular}{|c|c|c|c|c|c|c|}
\hline \multirow{2}{*}{ Variables } & \multicolumn{2}{|c|}{ 0\% BWS } & \multicolumn{2}{|c|}{$15 \%$ BWS } & \multicolumn{2}{|c|}{$30 \%$ BWS } \\
\hline & OG & $\mathrm{TM}$ & OG & TM & OG & TM \\
\hline $\begin{array}{l}\text { Mean speed } \\
(\mathrm{m} / \mathrm{s})\end{array}$ & $0.42(0.05)$ & $0.42(0.05)$ & $0.42(0.05)$ & $0.39(0.05)$ & $0.39(0.05)$ & $0.39(0.05)$ \\
\hline $\begin{array}{l}\text { Stance duration } \\
\text { (s) }\end{array}$ & $1.09(0.10)$ & $1.21(0.16)$ & $1.03(0.10)$ & $1.10(0.12)$ & $0.89(0.07)$ & $1.10(0.13)$ \\
\hline
\end{tabular}


Table 2 - Mean (means standard error) of mean walking speed, duration of stance period, single stance, total double stance and swing, step length, cadence, stride length and speed in the different experimental conditions $0 \%$, $15 \%$ and $30 \%$ body weight support (BWS), over the ground (OG) and on the treadmill (TM)

(Conclusion)

\begin{tabular}{|c|c|c|c|c|c|c|}
\hline \multirow{2}{*}{ Variables } & \multicolumn{2}{|c|}{$0 \%$ BWS } & \multicolumn{2}{|c|}{$15 \%$ BWS } & \multicolumn{2}{|c|}{$30 \%$ BWS } \\
\hline & OG & TM & OG & TM & OG & TM \\
\hline $\begin{array}{l}\text { Single stance } \\
(\%)\end{array}$ & 30 (1.31) & 27 (2.51) & $31(2.53)$ & 29 (2.23) & $36(2.84)$ & 29 (2.27) \\
\hline $\begin{array}{l}\text { Total double } \\
\text { stance (\%) }\end{array}$ & 38 (3.01) & $44(5.20)$ & 37 (5.62) & $40(4.89)$ & $26(5.66)$ & $39(4.73)$ \\
\hline Swing (\%) & 32 (1.71) & $29(2.74)$ & 32 (3.11) & 31 (2.68) & 38 (2.88) & $32(2.50)$ \\
\hline \multicolumn{7}{|l|}{ Step } \\
\hline Length (m) & $0.32(0.02)$ & $0.30(0.02)$ & $0.34(0.03)$ & $0.27(0.02)$ & $0.31(0.02)$ & $0.25(0.02)$ \\
\hline $\begin{array}{r}\text { Cadence (steps/ } \\
\text { min) }\end{array}$ & $81(5.80)$ & 76 (6.74) & 83 (5.96) & 80 (6.69) & $86(6.37)$ & $80(6.93)$ \\
\hline \multicolumn{7}{|l|}{ Stride } \\
\hline Length (m) & $0.63(0.04)$ & $0.60(0.04)$ & $0.66(0.05)$ & $0.54(0.04)$ & $0.59(0.04)$ & $0.51(0.03)$ \\
\hline Speed $(\mathrm{m} / \mathrm{s})$ & $0.43(0.04)$ & $0.38(0.05)$ & $0.46(0.05)$ & $0.36(0.04)$ & $0.42(0.04)$ & $0.34(0.04)$ \\
\hline
\end{tabular}

Considering that children with CP may present difficulties to walk, according to motor impairment, the BWS system used in this study provided reduction of both biomechanical overload and propulsive forces to transport the body forward $(17,28)$. This aspect might be verified through the reduction of stance duration as the body weight unloading increased, and probably facilitated lower limb movements and enabled children to walk with the same speed.

Up to now, there is not much available information concerning walking spatial temporal parameters of children with $\mathrm{CP}$, mainly related to body weight unloading. The results from this study revealed that the walking temporal organization was not influenced by the manipulation of either walking surface or body weight unloading, as the children maintained similar results related to healthy individuals (stance period, $60 \%$; swing period, $40 \%$ ) in all experimental conditions (29). These findings are in accordance with Patiño et al. (28), who observed that the manipulation of body weight unloading did not influence the walking temporal organization of healthy adults. This aspect might be considered positive in terms of walking intervention strategy for children with spastic CP, as it is possible to improve walking pattern without modifying temporal organization.

Another aspect found in the present study is related to step length and stride length and speed. In this study, only walking surface influenced these variables, wherein all of them decreased when the children walked on the treadmill. This result is accordance with previous investigations that compared walking on both surfaces $(25,30-32)$, and it can be attributed mainly to more instability provided by the treadmill, which is not the surface that these children usually walk. Last, these children presented similar cadence on both walking surfaces, independently of body weight unloading. This fact might be due to the walking speed that was kept the same in all experimental conditions, as these variables are directly related $(5,29)$. 
As this study was a first attempt to investigate a BWS system with servo motor and controlled by a computer program in children with CP under different motor impairment, some limitations may be point out. For example, a small and heterogenic sample was investigated and only some spatial-temporal parameters of walking were analyzed. However, it is important to note that this was a first attempt to analyze the behavior of these children with an innovative system. Such system allows not only its use on different walking surfaces as well as allows different combinations of body weight unloading on lower limbs, with a controlled walking speed. Future investigations with more children with spastic $\mathrm{CP}$ and with other analyses will be executed in order to improve our knowledge about the implications of using a BWS system on different walking surfaces and different body weight unloading.

Although there are some limitations and based upon the goals of this study, it is important to mention that in clinical terms, nowadays, it is more common to use a BWS system with treadmill during walking intervention. Some advantages may be point out for this type of interventions, for example, the reduced space to accommodate a treadmill and a better control of the number of steps by training session (17). On the other hand, walking on a treadmill is different from walking over ground in terms of propulsion and balance (33). In terms of the BWS system over ground, it was verified that it is one more choice to be adopted for gait intervention of children with $\mathrm{CP}$ and that can stimulate the execution of longer steps and strides and faster strides. Certainly, future studies aiming to investigate some other aspects of walking besides spatial temporal parameters and with a large number of children, and considering walking intervention with BWS system over ground and on treadmill will provide new insights for clinical settings.

\section{Conclusion}

Walking surface and body weight unloading might influence the way children with CP walk in terms of spatial temporal gait parameters. In terms of walking surface, the children presented longer steps and strides and faster strides as they walked over ground compared to the treadmill. In terms of body weight unloading, stance duration decreased as body weight unloading increased, though temporal organization, which was investigated throughout relative duration of single stance, total double stance and swing, was similar among experimental conditions.

\section{Acknowledgments}

Authors would like to thank the Fundação de Amparo à Pesquisa do Estado de São Paulo (FAPESP) for the financial support (Grant 2010/15218/3), Conselho Nacional de Desenvolvimento Científico e Tecnológico (CNPq) and Coordenação de Aperfeiçoamento de Pessoal de Nível Superior (CAPES) for the fellowship to G. S. C. Longuinho e M. L. Celestino, and also the children and their parents for participating in the study.

\section{References}

1. Rosenbaum P, Paneth N, Leviton A, Goldstein M, Bax $M$. A report: the definition and classification of cerebral palsy, April 2006. Dev Med Child Neurol. 2007; 49(Suppl 2):8-14.

2. Bax M, Goldstein M, Rosenbaum P, Leviton A, Paneth N, Dan B, et al. Proposed definition and classification of cerebral palsy, April 2005. Dev Med Child Neurol. 2005;47(8):571-6.

3. Mancini MC, Alves ACM, Schaper C, Figueiredo EM, Sampaio RF, Coelho ZAC, et al. Gravidade da paralisia cerebral e desempenho funcional. Rev Bras Fisioter. 2004;8(3):253-60.

4. Inman VT, Ralston HJ, Todd F. Human locomotion. In: Rose J, Gamble JG, editors. Human walking. 2nd ed. Baltimore: Williams \& Wilkins; 1994. p. 1-22.

5. Winter DA. The biomechanics and motor control of human gait: normal, elderly, and pathological. 2nd ed. Waterloo: University of Waterloo Press; 1991.

6. Chang FM, Rhodes JT, Flynn KM, Carollo JJ. The role of gait analysis in treating gait abnormalities in cerebral palsy. Orthop Clin North Am. 2010;41(4):489-506.

7. Cherng RJ, Liu CF, Lau TW, Hong RB. Effect of treadmill training with body weight support on gait and gross motor function in children with spastic cerebral palsy. Am J Phys Med Rehabil. 2007;86(7):548-55. 
8. Barbeau H. Locomotor training in neurorehabilitation: emerging rehabilitation concepts. Neurorehabil Neural Repair. 2003;17(1):3-11.

9. Therlkeld AJ, Cooper LD, Monger BP, Craven AN, Haupt HG. Temporospatial and kinematic gait alterations during treadmill walking with body weight suspension. Gait Posture. 2003;17(3):235-45.

10. Barbeau H, Fung J. The role of rehabilitation in the recovery of walking in the neurological population. Curr Opin Neurol. 2001;14(6):735-40.

11. Hesse S, Konrad M, Uhlenbrock D. Treadmill walking with partial body weight support versus floor walking in hemiparetic subjects. Arch Phys Med Rehabil. 1999;80(4):421-7.

12. Beard L, Harrow C, Bothner K. The effect of body weight support treadmill training on gait function in cerebral palsy: two case studies. Pediatr Phys Ther. 2005;17(1):72.

13. Miyai I, Fujimoto Y, Ueda Y, Yamamoto H, Nozaki S, Saito T, et al. Treadmill training with body weight support: its effect on Parkinson's disease. Arch Phys Med Rehabil. 2000;81(7):849-52.

14. Sullivan KJ, Knowlton BJ, Dobkin BH. Step training with body weight support: effect of treadmill speed and practice paradigms on poststroke locomotor recovery. Arch Phys Med Rehabil. 2002;83(5):683-91.

15. Visintin M, Barbeau H, Korner-Bitensky N, Mayo NE. A new approach to retrain gait in stroke patients through body weight support and treadmill stimulation. Stroke. 1998;29(6):1122-8.

16. Frey M, Colombo G, Vaglio M, Bucher R, Jorg M, Riener R. A novel mechatronic body weight support system. IEEE Trans Neural Syst Rehabil Eng. 2006; 14(3):311-21.

17. Norman KE, Pepin A, Ladouceur M, Barbeau H. A treadmill apparatus and harness support for evaluation and rehabilitation of gait. Arch Phys Med Rehabil. 1995; 76(8):772-8.

18. van Hedel HJ, Tomatis L, Muller R. Modulation of leg muscle activity and gait kinematics by walking speed and bodyweight unloading. Gait Posture. 2006; 24(1):35-45.
19. Harris-Love ML, Macko RF, Whitall J, Forrester LW. Improved hemiparetic muscle activation in treadmill versus overground walking. Neurorehabil Neural Repair. 2004;18(3):154-60.

20. Chao EY, Laughman RK, Schneider E, Stauffer RN. Normative data of knee joint motion and ground reaction forces in adult level walking. J Biomech. 1983; 16(3):219-33.

21. Alton F, Baldey L, Caplan S, Morrisey MC. A kinematic comparison of overground and treadmill walking. Clin Biomech. 1998;13(6):434-40.

22. Stolze H, Kuhtz-Buschbeck JP, Mondwurf C, BoczekFuncke A, Johnk K, Deuschl G, et al. Gait analysis during treadmill and overground locomotion in children and adults. Electroencephalogr Clin Neurophysiol. 1997;105(6):490-7.

23. Warabi T, Kato M, Kiriyama K, Yoshida T, Kobayashi N. Treadmill walking and overground walking of human subjects compared by recording sole-floor reaction force. Neurosci Res. 2005;53(3):343-8.

24. Lee SJ, Hidler J. Biomechanics of overground versus treadmill walking in healthy individuals. J Appl Physiol. 2008;104(3):747-55.

25. Matsuno VM, de Camargo MR, Alveno D, Palma GC, Barela AMF. Análise do uso de suporte parcial de peso corporal em esteira e em piso fixo durante o andar de crianças com paralisia cerebral. Rev Bras Fisioter. 2010;14(5):404-10.

26. Palisano R, Rosenbaum P, Walter S, Russell D, Wood E, Galuppi B. Gross motor function classification system for cerebral palsy. Dev Med Child Neurol. 1997; 39:214-23.

27. Sousa CO, Barela JA, Prado-Medeiros CL, Salvini TF, Barela AM. The use of body weight support on ground level: an alternative strategy for gait training of individuals with stroke. J Neuroeng Rehabil. 2009;6:43.

28. Patiño MS, Gonçalves AR, Monteiro BC, Santos IL, Barela AMF, Barela JA. Características cinemáticas, cinéticas e eletromiográficas do andar de adultos jovens com e sem suporte parcial de peso corporal. Rev Bras Fisioter. 2007;11(1):19-25.

29. Perry J. Gait analysis. Throfare: Slack; 1992. 
30. Bayat R, Barbeau H, Lamontagne A. Speed and temporal-distance adaptations during treadmill and overground walking following stroke. Neurorehabil Neural Repair. 2005;19(2):115-24.

31. Kautz SA, Bowden MG, Clark DJ, Neptune RR. Comparison of motor control deficits during treadmill and overground walking poststroke. Neurorehabil Neural Repair. 2011;25(8):756-65.

32. Brouwer B, Parvataneni K, Olney SJ. A comparison of gait biomechanics and metabolic requirements of overground and treadmill walking in people with stroke. Clin Biomech. 2009;24(9):729-34.
33. Goldberg EJ, Kautz SA, Neptune RR. Can treadmill walking be used to assess propulsion generation? J Biomech. 2008;41(8):1805-8.

Received: 03/12/2014

Recebido: 12/03/2014

Approved: 09/23/2014

Aprovado: 23/09/2014 